\title{
Confirmation of the Record of the Serpent Eel, Ophisurus serpens (Family: Ophichthidae) from Mersin Bay (NE Mediterranean, Turkey)
}

\author{
Deniz Erguden ${ }^{1}$, Yusuf Kenan Bayhan ${ }^{2}$, Sibel Alagoz Erguden ${ }^{3}$ and Ayhan Altun ${ }^{1}$ \\ 1. Department of Marine Sciences, Faculty of Marine Sciences and Technology, University of Iskenderun Technical, Iskenderun \\ 31220, Turkey \\ 2. Vocational School of Kahta, University of Adiyaman, Kahta 02400, Turkey \\ 3. Vocational School of Imamoglu, University of Cukurova, Imamoglu 01700, Turkey
}

\begin{abstract}
A specimen of the serpent eel, Ophisurus serpens, with a total length of $190.2 \mathrm{~cm}$ was caught off the coast of Mersin (Incekum), Turkey on November 2014 during trawling. This manuscript presents the first digitized specimen of $O$. serpens from the Mersin Bay (northeastern Mediterranean), and hence, confirms the presence of the species in the northeastern Mediterranean despite a suspicious previous report, possibly mistaken with Echelus myrus, of the species from Yumurtalık Bay. Remarks on the morphology and geographical distribution of the species in the Mediterranean Sea, Turkey are given.
\end{abstract}

Key words: Generalized extreme value distribution, ozone, selection of variables.

\section{Introduction}

The family Ophichthidae represented with about 290 species in the world, only five of which has been reported in Mediterranean waters [1]: Echelus myrus (Linnaeus, 1758), Dalophis imberbis (Delaroche, 1809), Pisodonophis semicinctus (Richardson, 1848), Ophisurus serpens (Linnaeus, 1758) and Ophichthus rufus (Rafinesque, 1810). The serpent eel, O. serpens is a benthic marine and brackish water species occurring from shallow waters to depths of 300-400 m [2, 3]. In the Mediterranean Sea $O$. serpens has been first reported from Gulf of Trieste, northern Adriatic Sea [4] and then, the northernmost area of the Adriatic Sea: Italy $[5,6]$; the western and central Mediterranean coasts [2, 7, 8]; the Alboran Sea [9]; the Ligurian Sea [10]; the Tunis Southern Lagoon [11]; and the northwestern Ionian Sea [12]; the Algarve coast (southern Portugal), near the Gibraltar Strait [13]; the Galician waters (northwestern,

Corresponding author: Deniz Erguden, master, main research fields: fish systematic, fish ecology.
Spain) [14]; the northwestern Ionian Sea, central Mediterranean [12, 15]; and also from the Greek waters of the north and central Aegean Sea: the Evvoikos Gulf $[16,17]$, the Korinthiakos Gulf [18] and the Saronikos Gulf [19]. In Turkish marine waters serpent eel, $O$. serpens was reported for the first time in 1966 from Aliağa (Çandarlı Bay) [20], and then three records of this species have been reported in southern and northern Aegean Sea, Turkey [21-25]. Although Sangun et al. [26] have reported fourty one $O$. serpens specimens without any description or data in the Turkish Mediterranean coast this may be a result of misidentification of the species since the species is highly rare in the area. It should be taken into account that the species has recently been reported a few times from Aegean waters [22-25] and possibly distributed to northern Mediterranean from there. Thus, the presence of $O$. serpens has remained doubtful for northeastern Mediterranean Sea until now.

Although O. serpens has distributed in the southern and northern Aegean Sea up to now, specimens of this 
species has not been reported in the Mersin Bay (north eastern Mediterranean) previously. The present paper reports the presence of $O$. serpens on the base of a single digitized record from the Mersin Bay and confirms the presence of the species in the northeastern Mediterranean, Sea Turkey.

\section{Material and Methods}

A single specimen of serpent eel $O$. serpens (Fig. 1) was caught during bottom trawling at $492 \mathrm{~m}$ depth, off İncekum, Mersin Bay (3607'679 N-3403'979 E), (Fig. 2) on November 6, 2014. Morphometric and meristic characters of the collected specimen were recorded. Morphometric measurements of the specimen were made to the nearest $0.01 \mathrm{~mm}$ using digital caliper. All measurements, morphological description and coloration of the serpent eel agree with previous descriptions by Bauchot [2], Ben Amor et al. [11], Torcu Koc and Erdogan [23].

\section{Results and Discussion}

Body is very elongated, and cylindrical and scaleless, snout long and conical with the upper jaw projecting. Jaws elongated and slender, teeth large caniniform and more or less curved and enlarged on premaxillae, small and biserial on maxillae. Small and uniserial teeth are on lower jaw. Vomerine uniserial teeth are enlarged anteriorly. Small anterior nostril is at mid snout. Eyes are relatively small. Dorsal and anal fins well developed; dorsal fin origin slightly behind the pectoral fins. Dorsal and anal fins ending near to the hardened caudal tip. Pectoral fins present, pelvic and caudal fins absents. Morphometric measurements and meristic counts are summarized in Table 1.

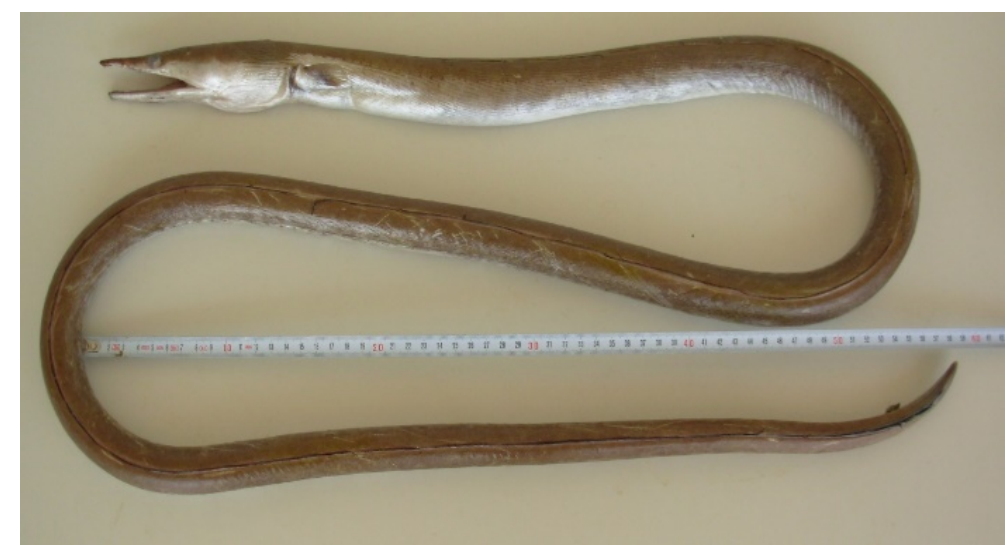

Fig. 1 The serpent eel, Ophisurus serpens caught off the Mersin Bay, Northeastern Mediterranean Sea.

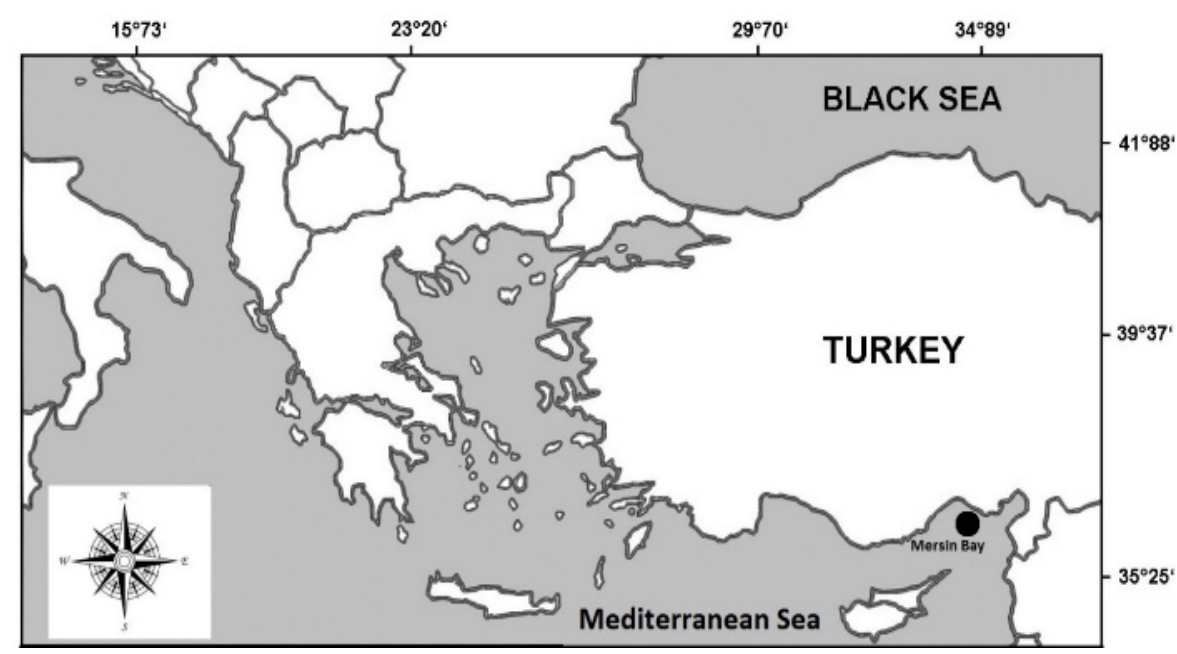

Fig. 2 Map showing the capture site (•) Ophisurus serpens in the NE Mediterranean Sea. 
Table 1 Morphometric and meristic features of Ophisurus serpens in Mersin Bay NE, Mediterranean, Turkey.

\begin{tabular}{ll}
\hline Morphometric & $\mathrm{mm}$ \\
\hline Total length & 1,902 \\
Pre-dorsal length & 214 \\
Pre-anal length & 718 \\
Body depth & 39.61 \\
Head length & 148.51 \\
Eye diameter & 10.26 \\
Pre-orbital length & 38.42 \\
Meristic & \\
Dorsal ray & 465 \\
Anal ray & 284 \\
Pectoral ray & 13 \\
The number of pores in linea lateralis & 205 \\
Weight & $1,320 \mathrm{~g}$ \\
\hline
\end{tabular}

Table 2 Previous records of Ophisurus serpens in Turkish marine waters.

\begin{tabular}{|c|c|c|c|c|c|c|}
\hline References & Location & Recorded date & Fishing gear & Depth (m) & $\begin{array}{l}\text { Number of } \\
\text { individuals }\end{array}$ & $\begin{array}{l}\text { Size } \\
(\mathrm{TL}, \mathrm{mm})\end{array}$ \\
\hline $\begin{array}{l}\text { Geldiay and Mater } \\
{[20]}\end{array}$ & $\begin{array}{l}\text { Aliağa Bay, } \\
\text { N Aegean Sea }\end{array}$ & 27 August 1996 & Lift Net & $35-40$ & 1 & - \\
\hline Karakulak et al. [25] & Gökçeada, N Aegean Sea & 2004-2005 & $\begin{array}{l}\text { Gill Net, } \\
\text { Trammel Net }\end{array}$ & $<30$ & 2 & $1,580-1,692$ \\
\hline Sangun et al. [26] & $\begin{array}{l}\text { Yumurtalık Bay, Eastern } \\
\text { Mediterranean }\end{array}$ & $2001-2003$ & Longline, Trawl & $5-100$ & 41 & $121-501$ \\
\hline Cengiz et al. [21] & Saros Bay, N Aegean Sea & $2005-2008$ & Trawl & $1-500$ & 1 & - \\
\hline Ulaş and Akyol [22] & Karaburun, N Aegean Sea & 2 March 2014 & Hand line & 32 & 1 & 1,917 \\
\hline $\begin{array}{l}\text { Torcu Koç and } \\
\text { Erdogan [23] }\end{array}$ & $\begin{array}{l}\text { Edremit Bay (Northern } \\
\text { Aegean Sea) }\end{array}$ & 15 January 2014 & Long line & 40 & 1 & 2,000 \\
\hline Filiz et al. [24] & Gokova Bay & 5 January 2015 & Purse seine & 55 & 1 & 1,212 \\
\hline This study & $\begin{array}{l}\text { Mersin Bay, } \\
\text { NE Mediterranean }\end{array}$ & 6 November 2014 & Bottom Trawl & 492 & 1 & 1,902 \\
\hline
\end{tabular}

Color: Body coloration dorsally brownish and ventrally yellowish-white; snout light ochre; dorsal and anal fins edged with greyish; lateral and cephalic pores blackish. Data on the occurrence and of $O$. serpens in marine waters of Turkey are summarized in Table 2.

The serpent eel, $O$. serpens is a cosmopolitan species widely distributed in the Atlantic Ocean (northern coast of Iberian peninsula to South Africa, and also Madeira) and the Indo-Pacific Ocean (southern Mozambique to South Africa; north to Japan, south to Australasia) [2, 27]. This species is very rare in the Aegean Sea and Mediterranean Sea, Turkey, where it generally lives between $30 \mathrm{~m}$ and $400 \mathrm{~m}$ depth on sandy and sandy-muddy bottom [28]. It feeds mainly on benthic invertebrates and fish, and its average size is between $50 \mathrm{~cm}$ and $150 \mathrm{~cm}$ with a maximum of $240 \mathrm{~cm} \mathrm{[29].}$
A previous record of the species from the Turkish Mediterranean waters [26], should probably be considered as a misidentification of Echelus myrus. Ulaş and Akyol [22] claim that this species rarely occurs in the northern and southern Aegean Sea. Nevertheless, Sangun et al. [26] reported the handling of 41 specimens from eastern part of the Mediterranean Sea for a length-weight relationship research (at depth ranging from 5 to 100 meters). However, no description, concerning metric and meristic characters, of the species has been included in their article. Occurrence of considerable high number of the specimens is highly doubtful and needs confirmation with supporting materials such as description and pictures. Thorough reviews of previous studies [30-32] have revealed no indication of the presence of $O$. 
serpens in the eastern and western Mediterranean Sea of Turkey.

\section{Conclusion}

Although the serpent eel, $O$. serpens has been reported for several times in the Aegean Sea, Turkey (Table 2) up to now, there was no report of the eastward expansion of the distribution of this species to the north-eastern Mediterranean Sea (Mersin Bay). This paper confirms the presence of the species in the north-eastern Mediterranean, and hence expansion of the occurrence area of the species.

Recent investigations conducted regularly and permanently in Turkish marine waters, especially in north-eastern areas of Mediterranean Sea, allowed capture of rare specimens just like the one presented and described in this paper. Hence, authors' finding from Mersin Bay is the first confirming report of this species from the NE Mediterranean Sea, Turkey. The occurrence of this species in the northeastern part of the Mediterranean Sea might be due to changing trophic or ecological conditions of these marine ecosystems.

\section{Acknowledgement}

Authors would like to thank, the owner of the Çinar Bey Boat, Captain Murat ÇINAR and the boat crew for their assistance in this study.

\section{References}

[1] Quéro J. C., Porche, P., and Vayne, J. J. 2003. Guide des Poissons de l'Atlantique européen. Les Guides du Natura liste. Paris, France: Delachaux \& Niestlé.

[2] Bauchot, M. L. 1986. "Ophichthidae (including Echelidae)." In Fish of the North-Eastern Atlantic and the Mediterranean, edited by Whitehead, P. J. P, Bauchot, M. L., Hureau, J. C., Nielsen, J., and Tortonese, E. Paris: UNESCO.

[3] May, J. L., and Maxwell, J. G. H. 1986. Trawl Fish from Temperate Waters of Australia. Tasmania: CSIRO Division of Fisheries Research.

[4] Perugia, A. 1866. Catalogodei Pesci dell'Adriatico. Trieste: Civico Museo Ferdinando Massimiliano.

[5] Dulcic, J., Matic-Skoko, S., and Kraljevic, M. 2005.
"New Record of Serpent Eel Ophisurus serpens (Linnaeus, 1758) (Ophichthidae) in the Adriatic Waters with a Review of Recent Adriatic Records." Annales, Series Historia Naturalist 15: 181-4.

[6] Bettoso, N., and Comisso, G. 2005. "Recent Record of the Serpent Eel Ophisurus serpens (Pisces: Ophichthidae) in the Gulf of Trieste (Northern Adriatic Sea)." Annales, Series Historia Naturalist 25 (2): 141-4.

[7] Tortonese, E. 1970. Osteichthyes (Pesci ossei). Fauna d'Italia. Parte Prima. Bologna: Calderini.

[8] Biagi, F., Sartor, P., Ardizzone, G. D., Belcari, P., Belluscio, A., and Serena, F. 2002. "Analysis of Demersal Assemblages of the Tuscany and Latium Coasts (North-Western Mediterranean)." Scienta Marina 66 (S2): 233-42.

[9] Abad, E., Preciado, I., Serrano, A., and Baro, J. 2007. "Demersal and Epibenthic Assemblages of Trawlable Grounds in the Northern Alboran Sea (Western Mediterranean)." Scienta Marina 71 (3): 513-24.

[10] Relini, G., Relini, M., Palandri, G., Merello, S., and Beccornia, E. 2007. "History, Ecology and Trends for Artificial Reefs of the Ligurian Sea, Italy." Hydrobiologia 580 (1): 193-217.

[11] Ben Amor, M. M., Ben Souissi, J., Ben Salem, M., and Capapé, C. 2009. "Confirmed Occurrence of the Longjaw Snake Eel, Ophisurus serpens (Osteichthyes: Ophichthidae) in Tunisian Waters (Central Mediterranean)." Pan-American Journal of Aquatic Sciences 4 (3): 251-4.

[12] Maiorano, P., Sion, L., Carlucci, R., Capezzuto, F., Giove, A., Costantino, G., et al. 2010. "The Demersal Fauna Assemblage of the North-Western Ionian Sea (Central Mediterranean): Current Knowledge and Perspectives." Chemical Ecology 26 (S1): 219-40.

[13] Borges, T. C., Olim, S., Erzini, K. 2003. "Weight-Length Relationships for Fish Species Discarded in Commercial Fisheries of the Algarve (Southern Portugal)." Journal of Applied Ichthyology 19 (6): 394-6.

[14] Bañón, R., Valeiras, J., Armesto, C., and Abad, M. 2011. "Occurrence of Ophisurus serpens (Anguilliformes, Ophichthidae) from Galician Waters (NW Spain)." Cybium 35: 157-8.

[15] Kaspiris, P. 1984. "Anguilliformes from the Western Coasts of Greece.” Biologia Gallo-Hellenica 11: 27-30.

[16] Papaconstantinou, C., Petrakis, G., Mytilineou, C. H., Politou, C. Y., and Vassilopoulou, V. 1994. "The Fish Fauna of the Eastern Coast of Greece.” Biologia Gallo-Hellenica 22: 363-74.

[17] Stergiou, K. I., Politou, C. Y., Christou, E. D., and Petrakis, G. 1997. "Selectivity Experiments in the NE Mediterranean: the Effect of Trawl Codend Mesh Size on Species Diversity and Discards." ICES Journal of Marine 


\section{Confirmation of the Record of the Serpent Eel, Ophisurus serpens (Family: Ophichthidae) from Mersin Bay (NE Mediterranean, Turkey)}

Science 54 (5): 96-102.

[18] Kaspiris, P. 1973. "Contribution to the Study of Osteichthyes of the Korinthiakos and Patraikos Gulf and the Ionian Sea." Ph.D. thesis, Univeristy of Patras, Greece.

[19] Papaconstantinou C., and Tsimenidis, N. 1979. "Some Uncommon Fishes from the Aegean Sea." Cybium 3 (7): 3-14.

[20] Geldiay, R., and Mater, S. 1968. "Two Species of Fish Found in the Aegean Sea (Oxynatus centrina L. and Ophisurus serpens L.). İzmir, Turkey." Ege University Scientific Report of the Faculty of Science 52: 1-8.

[21] Cengiz, Ö., Işmen, A., Ozekinci, U., and Oztekin, A. 2011. "An Investigation on Fish Fauna of Saros Bay (Northern Aegean Sea)." AKU Journal of Science 11: 31-7.

[22] Ulaş, A., and Akyol, O. 2015. "Occurrence of the Serpent Eel, Ophisurus serpens (Linnaeus, 1758) (Osteichthyes: Ophichthidae), Close to the Bay of İzmir (Aegean Sea, Turkey)." Turkish Journal of Zoology 39 (1): 191-3.

[23] TorcuKoç, H., and Erdoğan, Z., 2015. "Confirmed Occurence of the Longjaw Snake Eel, Ophisurus serpens (Osteichthyes: Ophichthidae) in Edremit Bay (Northern Aegean Sea), Turkey." Turkish Journal of Fisheries Aquatic Science 15 (2): 371-4.

[24] Filiz, H, Ateş, C., Yapici, S., and Ağdamar, S. 2015. "Filling the Gap: First Confirmed Record for the Ophisurus serpens (Anguilliformes: Ophichthidae) from the Anatolian Coast of the South Aegean Sea." Marine Biodiversity Records 8: 63.

[25] Karakulak, F. S., Erk, H., and Bilgin, B. 2006. "Length-Weight Relationships for 47 Coastal Fish Species from the Northern Aegean Sea, Turkey." Journal of Applied Ichthyology 22 (4): 274-8.

[26] Sangun, L., Akamca, E., and Akar, M. 2007. "Weight-Length Relationships for 39 Fish Species from North-Eastern Mediterranean Coast of Turkey." Turkish Journal of Fisheries Aquatic Science 7 (1): 37-40.

[27] Froese, R., and Pauly, D. 2016. "Fishbase." World Wide Web Electronic Publication. Accessed June 23, 2016. http://www.fishbase.org.

[28] Jardas, I. 1996. Adriatic Ichthyofauna. Zagreb: Školska Knjiga.

[29] Golani, D., Ozturk, B., and Basusta, N. 2006. Fishes of the Eastern Mediterranean. Istanbul: Turkish Marine Research Foundation (TUDAV).

[30] Gücü, A. C., and Bingel, F. 1994. "Trawl able Species Assemblages on the Continental Shelf of the Northeastern Levant Sea (Mediterranean).” Acta Adriatica 35 (1): 83-100.

[31] Basusta, N., and Erdem, Ü. 2000. "A Study on the Pelagic and Demersal Fishes of Iskenderun Bay." Turkish Journal of Zoology 24 (Suppl 1): 1-19.

[32] Begburs R. C., and Kebapcioğlu T. 2007. "An Investigation on Catch Composition of Bottom Trammel Nets Used in Antalya Boğazkent." Ege Journal of Fisheries Aquatic Science 24 (3): 283-6. 